УДК 37. 013: 002. 2(091) «1926/1936»

DOI: $\underline{10.35619 / \text { iiu.v1i11.257 }}$

Баліка Людмила

кандидат педагогічних наук, доцент, доцент кафедри теорії і методики виховання Рівненського державного гуманітарного університету, м. Рівне, Україна

ORCID: 0000-0003-0042-7744

e-mail: liudmyla.balika@rshu.edu.ua

\title{
СПЕЦИФІКА ДІЯЛЬНОСТІ КАБІНЕТУ ВИВЧЕННЯ КНИГИ І ЧИТАЧА В УКРАЇНСЬКОМУ НАУКОВОМУ ІНСТИТУТІ КНИГОЗНАВСТВА (1926-1936)
}

Анотація. Констатовано, що в Україні спостерігається зниження інтересу до читання. Кризу читання визнано на державному рівні. Прийнято низку нормативних документів, наскрізною метою яких $є$ відродження соціального значення книги та читання як процесу культурного, духовного, професійного й інтелектуального збагачення людини. Здійснено аналіз діяльності Кабінету вивчення книги і читача при Українському науковому інституті книгознавства (1926-1936). Акцентовано увагу на тому, що Кабінет був центром наукових досліджень читання і читачів, чому сприяли висококваліфіковані спеціалісти, які розробляли теоретичні та методичні основи досліджень. Зазначено, що в свій час Кабінет очолювали В. М. Іванушкін (1926-1927), Д. А. Балика (1927-1930), Н. М. Біркіна (1931-1936). Виокремлено основні теоретичні проблеми, над якими планував працювати Кабінет: психологія книжкового впливу загалом; зміст книги 3 погляду бібліопсихології; читачіство як проблема літературознавства; психологія сприймання літературного твору; місце історії читача в історії літератури; історія читача в Україні; принципи побудови популярної книги; сучасна українська популярна книга та ін. Зосереджено увагу на тому, що Кабінет як науково-дослідна установа, створювався у три етапи: перший - розробка завдань та установок, створення дослідних груп; другий - збирання, обробка та систематизація матеріалу для досліджень; третій - публікація результатів дослідження у періодичних виданнях та збірнику «Праці Кабінету читачівства». Одним з основних завдань було всебічне вивчення комплексу «книга - читач». 3'ясовано, що діяльність Кабінету була спрямована на організацію та проведення Всеукраїнського обстеження стану бібліотек та їхньої роботи з читачами, вивчення читацького попиту в бібліотеках, дослідження читання художньої літератури робітничою молоддю у бібліотеках.

Ключові слова: Кабінет вивчення книги і читача, Український науковий інститут книгознавства, комплекс «книга - читач», В. М. Іванушкін, Д. А. Балика, Н. М. Біркіна, вітчизняні освітньо-культурні інституції 1920-1930 рр.

Постановка проблеми. Нині в Україні спостерігається тенденція до зниження читання серед широких мас населення. Причини цього процесу - наслідок технічного прогресу, прискорення ритму життя, бурхливий розвиток новітніх інформаційних технологій. Кризу читання в Україні визнано на державному рівні. Для іiі подолання урядом схвалено низку документів, як-от: «Концепція державної політики щодо розвитку національної видавничої справи та популяризації читання 
на період до 2020 року» (Кабінет Міністрів України, 2016), «Стратегія розвитку бібліотечної справи на період до 2025 року «Якісні зміни бібліотек для забезпечення сталого розвитку України» (Кабінет Міністрів України, 2016). Наскрізною метою реалізації вказаних документів $є$ відродження соціального значення книги та читання як процесу культурного, духовного, професійного й інтелектуального збагачення людини, що уможливить підвищення рівня конкурентоспроможності України як європейської держави.

Тому актуальним $\epsilon$ вивчення досвіду бібліотек, інших соціальних інституцій 1920-1930 pр., коли рівень освіченості населення був низьким, і зацікавлення населення книжкою, читанням було нагальною проблемою. Аналізу, на нашу думку, потребує діяльність специфічних закладів, приміром, Українського наукового інституту книгознавства (УНІК), оскільки творчі здобутки його працівників ще належно не досліджені і не оцінені.

Аналіз останніх досліджень 3 проблеми показав, що історики, бібліотекознавці, педагоги досліджували окремі аспекти діяльності Українського наукового інституту книгознавства (УНІК), який функціонував у Києві в 19201930-х роках (Ковальчук, 2015; Новальська, 2004). О. Лопата вивчала інформаційні потреби читача в контексті бібліотечної практики 20 -х - початку 30 -х років XX століття (Лопата, 2011); I. Тимошенко аналізувала творчі здобутки співробітників Кабінету по вивченню книги і читача (Тимошенко, 1999).

Мета статті - проаналізувати організаційно-методичну роботу Кабінету вивчення книги і читача в Українському науковому інституті книгознавства (19261931); вирізнити позитивні здобутки діяльності Кабінету.

Виклад основного матеріалу дослідження. 1 жовтня 1926 року в Українському науковому інституті книгознавства (науково-дослідна установа, що існувала в Києві в 1922-1936 роках і була підпорядкована Народному комісаріату освіти УСРР) було відкрито «Кабінет вивчання книги й читача», основним завданням якого було вивчення не просто книги, а комплексу «книга - читач», розробка методів обслуговування читача в бібліотеці та методів самоосвіти. Кабінет вивчення книги й читача ставив перед собою теоретичні та практичні завдання. До теоретичних належали: проблеми книжкового впливу на читача, методи обслуговування читачів у бібліотеці, методи самоосвіти, раціоналізації книговидачі; методика керування читанням, самоосвітою загалом, перехід у цьому плані від кустарництва до науково-упорядкованої системи; дослідження фізіологічного впливу книги у процесі читання, окреслення шляхів боротьби 3 негативними наслідками читання книжок, розробка практичної гігієни книжки. Практичне завдання Кабінету: вивчати масові запити читачів, досліджувати іх закономірність і на грунті цього вносити корективи у видавничу справу (Ковальчук 2015, c. 287).

У 1926 р. під керівництвом В. М. Іванушкіна Кабінет став центром наукових досліджень читання і читачів. Цьому сприяли висококваліфіковані спеціалісти, які розробляли теоретичні та методичні основи досліджень. Необхідний для вивчення матеріал збирався за допомогою «спостерігачів» - дописувачів, бібкорів (бібліотечні спостерігачі), а саме: бібліотекарів, учителів, клубних працівників, літературних діячів, працівників книгарень, видавництв, які діяли згідно Інструкцій Кабінету. За допомогою бібкорів, Кабінет збирав матеріал про читацькі інтереси, стан роботи з читачами міських та сільських бібліотек. Працівники Кабінету намагалися розробити систему своєрідних дослідницьких пунктів, завдяки яким робота носила б не кабінетний характер, а теоретичні й методичні положення постійно перевірялися б на практиці. 
Діяльність Кабінету як науково-дослідної установи можна умовно розділити на три етапи: перший - розробка завдань та установок, створення дослідних груп; другий - збирання, обробка та систематизація матеріалу для досліджень; третій публікація результатів дослідження у періодичних виданнях та збірнику «Праці Кабінету читачівства».

Основним завданням Кабінету, як зазначалося вище, було всебічне вивчення комплексів «книга - читач». В. Іванушкін працював над теоретичним обгрунтуванням цього завдання: у праці «Проблема читачівства та іiї вивчення» (Іванушкин, 1926) він виокремив форми організації та методи роботи Кабінету. Значна частина брошури присвячена вивченню читача, під яким В. Іванушкін розумів «соціологічну постать, що вступає у певний конфлікт зі змістом та формою книжки. Цей конфлікт є складовою частиною діалектичного процесу читання та засвоєння книжки» (Іванушкин, 1926, с. 19). Бібліотекознавець вважав, що дослідження читача потрібно проводити поза його увагою та весь процес ділив на три стадії: дослідження окремих читачів; типізація читачів за окремими ознаками; класифікація читачів за групами, за сукупністю найважливіших ознак. Він звернув увагу на необхідність вивчення окремого читача, а не групи. В. Іванушкін заклав теоретичні та методичні засади комплексу «книга - читач», обгрунтував мету та завдання Кабінету.

I. Тимошенко виокремила основні теоретичні проблеми, над якими планував працювати Кабінет: психологія книжкового впливу загалом; зміст книги з погляду бібліопсихології; бібліопсихологічна теорія М. О. Рубанкіна і марксистська психологія; читачіство як проблема літературознавства; психологія сприймання літературного твору; місце історії читача в історії літератури; історія читача в Україні; принципи побудови популярної книг; сучасна українська популярна книга; техніка книги з погляду потреб масового читача; методика самоосвіти в світі бібліопсихології; патологія книги й боротьба з нею (Тимошенко, 1999, с.18).

У 1927 році Кабінет розпочав Всеукраїнське бібліотечне обстеження, перейшовши від безсистемного збирання матеріалу до чіткої роботи. Обстеження було доручено спеціальній комісії, до складу якої ввійшли Д. Балика, А. Вияснівський, К. Довгань, М. Іванченко, Г. Марголіна, Ю. Меженко, Н. Фрідьєва. Планувалося охопити всі бібліотеки, що мали в громадському користуванні не менше 100 книг. Анкетування було визнано як найдоцільніший засіб дослідження стану бібліотек України та їхньої роботи з читачами. Було розроблено стандартизовану «Анкету в справі дослідження стану бібліотек України та їх роботи з читачем». У Поясненні до анкети було зазначено:

1. «Анкета має на меті виявити стан бібліотек та їхньої роботи з читачем. Матеріали цієї анкети 1) ляжуть в основу наукового вивчення бібліотечної справи в Україні - особливо роботи з читачем - і бібліотечної статистики, і 2) дадуть змогу виявити й сформувати той широкий актив бібліотечних робітників, яких можна буде притягти до ближчої участі в роботі Кабінету і на яких Кабінет у цій роботі буде спиратися.

2. Певна річ, що в цій анкеті, для різних бібліотек призначеній, $є$ кілька питань, що неоднаково відповідатимуть бібліотекам різних типів. Може трапитись так, що не всі бібліотеки зможуть дати точні відповіді на всі питання (краще зовсім не відповісти на якесь питання, ніж давати відповідь неправдиву і надуману).

3. Цю анкету мають заповнити всі чисто бібліотеки в Україні різних типів і розмірів. За бібліотеку треба вважати збірку книг числом не менше як 100 книг, 3 якої постійно користується певне коло читачів. 
4. Уся анкета поділяється на 14 розділів. Відповіді на питання розділів $1-7$ та 13-14 треба записувати в самій анкеті. Щодо розділів 8-12, то відповіді на них мають бути широкі й докладні, тому треба подавати їх на окремих аркушах» (Ковальчук, 2015, с.294).

В Українському науковому інституті книгознавства планувалося анкетування провести до 25 травня 1927 року, однак анкети надходили ще до кінця грудня, проте були бібліотеки, які проігнорували анкетування. Низький відсоток одержаних анкет знецінив здобутки Всеукраїнського обстеження, тому питання про читача та методику бібліотечної роботи з ним не мало належного висвітлення.

Із жовтня 1927 р. по 1930 р. кабінет очолював Д. А. Балика. Він розробив програму роботи Кабінету, в якій передбачив укладення низки картотек з проблеми читачіства: формування спеціальної бібліотеки з вивчення читачівства; розробку анкети обстеження бібліотек і публікацію статей і покажчиків; з'ясування низки питань, пов'язаних із використанням книги в бібліотечній практиці та ін. Бібліотекознавець намагався змінити загальну спрямованість книгознавства, висуваючи на перший план актуальні проблеми.

У 1927-1928 академічному році було враховано, що умови роботи міських та сільських бібліотек були неодинакові, тому Кабінет почав використовувати різноманітні методи вивчення читацьких інтересів. Кабінет згрупував бібкорів за типами бібліотек, досліджував окремі питання за певним планом та збирав матеріали лише в межах конкретного завдання. Це давало змогу організувати обстеження бібліотек в однакових умовах, об'єднувати й порівнювати між собою матеріали з вивчення однорідних або близьких між собою читацьких груп.

330 січня по 14 квітня 1928 року працівниками Кабінету було проведено дослідження читацького попиту в політосвітніх, робітничих i вишівських бібліотеках, з урахуванням мотиву попиту як однієї з характеристик читача (Демчук, 2008). Було розроблено картки попиту, які містили такі питання: назва бібліотеки, номер читача, яку книгу повернув читач, що запитав, записано дослівно чи ні, що видано (автор, назва), книга не видана (на руках, нема в бібліотеці), чоловік чи жінка, вік, національність, член спілки (якої), фах, посада, де працює, член КП(б)У, кандидат, член ЛКСМУ, кандидат, безпартійний, яку школу і скільки класів закінчив, де вчиться тепер (Ковальчук, 2015, с.299).

У результаті цього дослідження було зібрано близько 6,5 тис. заповнених карток від 41 бібліотеки. Було досліджено, що українська поезія не користується попитом; «загальна політична кваліфікація» молодих робітників, значно вища за літературну (Ковальчук, 2015, с.300).

У сільських читальнях не було можливості визначити попит на книговидачу за допомогою читацьких формулярів, бо їх бібліотекарі не вели. Дослідження інтересів читачів проводилося методом голосних читань 3 наступним обговоренням прочитаного, з відповідним протоколюванням, перевіряючи у такий спосіб, як сприймає сільський читач різні твори художньої літератури. Мета голосних читань була прописана в інструкції Кабінету: «Видавництву треба знати думку селян про певну книгу, щоб бачити, чи варто книгу видавати» (Ковальчук, 2015, c.301).

Для вивчення інтересів читачів-селян була розроблена картка дослівного запису попиту читача. До українського наукового інституту книгознавства повернулося майже три тисячі заповнених анкет. Ці анкети знаходяться в архіві інституту та досі належним чином не опрацьовані. Хоча вони є безцінними для історії бібліотечної справи України з вивчення тогочасних бібліотек, їх книжкових фондів, персоналу, методики роботи з читачем, запитів і читацьких уподобань. 
Для вивчення попиту читача працівниками Кабінету було розроблено листівкизвернення, які вкладалися у наявні в бібліотеці книги або щойно випущені. За 19281932 рр. в Інститут прийшло понад півтори тисячі листів-відгуків на прочитані книги. Як засвідчують листи та статистичні зведення Кабінету, найбільшим попитом у сільських читачів на час бібліотечного обстеження користувалися твори українських письменників В. Винниченка, М. Коцюбинського, I. Франка, T. Шевченка, Марка Вовчка. Не користувалися попитом філософська література, праці з математики, мовознавства та ін. Натомість сільськогосподарська література та твори «старих» українських письменників були цікаві для сільського читача. Зведена Кабінетом інформація давала змогу зробити висновок, що читачам цієї категорії потрібна популярна література, дитячі книжки, пригоди, твори українського радянського письменства (Ковальчук, 2015, с.302-303).

Дослідження виявило різний освітній рівень бібліотекарів (більшість мали середню та початкову освіту, спеціальну бібліотечну підготовку мали лише 24,4 \% працівників).

Результатом вивчення зібраних Кабінетом матеріалів були статті Д. Балики: «Аналітичний та синтетичний метод вивчення читачівства», «Про класифікацію друків за соціяльним призначенням», «Ще про наукові та організаційні проблеми книговивчення» та «Бібліологічна педагогіка як наука». Частину матеріалів було оформлено у вигляді статей та об’єднано в збірник «Бібліотека і читач на Україні / Праці Кабінету вивчання книги й читача» і видано друком як другий том «Трудів Інституту книгознавства» (Бібліотека і читач на Україні: Праці Кабінету вивчання книги й читача, 1930). У збірнику також вміщені доповіді, виголошені в Кабінеті вивчення книги й читача: Н. Фрідьєвої «Читач київських політосвітніх бібліотек у 1926/27 р.», тези до доповіді Д. Балики «Проблема вивчання читача в історії літератури та книгознавства», Д. Ігудесмана «Вивчання читача в Америці за національною ознакою», В. Шпілевич «Матеріали до історії земських народних бібліотек на Україні».

Співробітники Кабінету проводили засідання Секції соціології книги УНІК, на яких обговорювалися проблеми бібліотекознавства та книгознавства.

У 1931-1936 рр. в українській науці, культурі та літературі відповідно до змін політичного курсу, розпочалася боротьба з «ворожими ідеями», «буржуазним націоналізмом». Нищівній критиці був підданий Український науковий інститут книгознавства, зокрема й Кабінет, його наукові здобутки в бібліографії, книгознавстві, бібліотекознавстві. 31930 по 1936 рік назва Кабінету змінювалася декілька разів: Кабінет вивчення читача, Кабінет читача, Кабінет читачіства, Кабінет вивчання споживача книги, Споживача книги та преси й ін. Кабінет майже рік працював без керівника. Завідувачкою кабінету у 1931-1936 pp. була Н. М. Біркіна, яка, на вимогу партійної ідеології, почала вести «боротьбу, хоч і неактивну, протибуржуазного книгознавства» (Ковальчук, 2015, с.157), виступала 3 ідеєю реорганізації Інституту: «партійне керівництво, «партизація і комсомолізація» колективу на 50 \%» (Ковальчук, 2015, с. 177). У 1933 р. Надія Біркіна виступила 3 доповіддю «Проти еклектизму в питаннях читачівства», у якій практично політичними гаслами підмінила наукову роботу (Ковальчук, 2015, c.339).

Фактично діяльність Кабінету в останні роки його функціонування зосередилася на вивченні ленінського книгознавства та «початківських читачівських груп», читанні робітниками військової книги.

Український науковий інститут книгознавства функціонував до літа 1936 року, коли Постановою Ради народних комісарів УРСР від 13 червня 1936 р. «Про 
реорганізацію науково-дослідного інституту книгознавства» він був реорганізований у Науково-методичний кабінет бібліотекознавства i масової бібліографії при Бібліотечному управлінні, утвореному в 1934 р. при Наркомосвіти УРСР (Постанова Ради народних комісарів УРСР, 1936). Власне це означало не тільки припинення діяльності Кабінету, вивчення книги і читача Українського наукового інституту книгознавства, але й кінець розвитку книгознавства в Україні.

Висновки і перспективи подальших розвідок. Отже, аналіз діяльності Кабінету вивчення книги й читача в Українському науковому інституті книгознавства (1926-1936 рр.) дає підстави стверджувати, що діяльність Кабінету здійснила значний внесок у розвиток українського бібліотекознавства. Одним 3 основних завдань Кабінету було всебічне вивчення комплексу «книга - читач». Кабінет був центром наукових досліджень читання і читачів, якому сприяли висококваліфіковані спеціалісти, що розробляли теоретичні та методичні основи досліджень. Основними теоретичними проблемами, над якими працював Кабінет, були: психологія книжкового впливу загалом; зміст книги 3 погляду бібліопсихології; читачіство як проблема літературознавства; психологія сприймання літературного твору; місце історії читача в історії літератури; історія читача в Україні; принципи побудови популярної книги; сучасна українська популярна книга та ін. 3'ясовано, що діяльність Кабінету була спрямована на організацію та проведення Всеукраїнського обстеження стану бібліотек та їхньої роботи з читачами, вивчення читацького попиту в бібліотеках, дослідження читання художньої літератури робітничою молоддю у бібліотеках.

Перспективи подальших наукових розвідок вбачаємо у вивченні найбільш популярних форм роботи Кабінету вивчення книги i читача, можливості й доцільності їх творчого застосування в сучасних умовах.

\section{СПИСОК ВИКОРИСТАНИХ ДЖЕРЕЛ}

Кабінет Міністрів України. (2016). Конщепція державної політики щзодо розвитку національної видавничої справи та популяризачії читання на період до 2020 року». URL: https://zakon.rada.gov.ua/laws/show/111-2016-\%D1\%80 [дата звернення 2 травня 2020[.

Кабінет Міністрів України. (2016). Стратегія розвитку бібліотечної справи на період до 2025 року «Якісні зміни бібліотек для забезпечення сталого розвитку Украӥни». URL: https://www.kmu.gov.ua/npas/248924865 [дата звернення 2 травня 2020].

Ковальчук, Г. (2015). Украӥнський науковий інститут книгознавства (19221936). Київ: Академперіодика, 688 с.

Новальська, Т. (2004). УНІК-перша науково-дослідна установа 3 вивчення проблем українського читачезнавства. Бібліотечний вісник. № 1. с. 36-39.

Лопата, О. (2011). Дослідження інформаційних потреб читача в контексті бібліотечної практики $20-\mathrm{x}$ - початку $30-\mathrm{x}$ років XX століття. Вісник Книжкової палати. № 7, сс. 1-6.

Тимошенко, І. (1999). Діяльність Кабінету по вивченню книги і читача в УНІК (1926-1931). Бібліотечний вісник. № 2. С. 17-20.

Іванушкин, В. (1926). Проблема читачівства та ї̈ вивчення (Форми організації та методи роботи Кабінету вивчення книжки та читача при У.Н.-Д.І.К.). Київ : УНІК, 1926. $32 \mathrm{c}$.

Демчук, Н. (2008). Синкретична природа теорії бібліопедагогіки та бібліопсихології (компаративістична студія книгознавчих парадигм Д. Балики та 
М. Рубакіна). Вісник Львівського університету. Серія книгознавство, бібліотекознавство та інформаційні технології. Львів, Вип. 3. С. 174

Бібліотека і читач на Украӥні: Праці Кабінету вивчання книги й читача: зб. перший / за ред. Д. Балики. (1930); Труди УНІК. Т. 2. Харків ; Київ : ДВУ, 240 с.

Постанова Ради народних комісарів УРСР «Про реорганізацію науководослідчого інституту книгознавства» (1936). Бібліотека у соиіалістичному будівництві. № 9. С. 51.

\section{REFERENCES}

Kabinet Ministriv Ukrainy. (2016). Kontseptsiia derzhavnoi polityky shchodo rozvytku natsionalnoi vydavnychoi spravy ta populiaryzatsii chytannia na period do 2020 roku». [The Concept of State Policy for the Development of National Publishing and Popularization of Reading for the Period up to 2020"]. URL: https://zakon.rada.gov.ua/laws/show/111-2016-\%D1\%80 [data zvernennia 2 travnia 2020]. (in Ukrainian)

Kabinet Ministriv Ukrainy. (2016). Stratehiia rozvytku bibliotechnoi spravy na period do 2025 roku «Iakisni zminy bibliotek dlia zabezpechennia staloho rozvytku Ukrainy»». [Strategy for the Development of Librarianship until 2025 "Qualitative Changes in Libraries to Ensure Sustainable Development of Ukraine"]. URL: https://www.kmu.gov.ua/npas/248924865 [data zvernennia 2 travnia 2020]. (in Ukrainian)

Kovalchuk, H. (2015). Ukrainskyi naukovyi instytut knyhoznavstva (1922-1936). [Ukrainian Scientific Institute of Bibliology (1922-1936)]. Kyiv: Akademperiodyka, 688 s. (in Ukrainian)

Novalska, T. (2004). UNIK-persha naukovo-doslidna ustanova z vyvchennia problem ukrainskoho chytacheznavstva. [UNIK - the First Research Institution to Study the Problems of Ukrainian Readership]. Bibliotechnyi visnyk. No 1, s. 36-39. (in Ukrainian)

Lopata, O. (2011). Doslidzhennia informatsiinykh potreb chytacha v konteksti bibliotechnoi praktyky 20-kh - pochatku 30-kh rokiv XX stolittia. [Research of the Information Needs of Reader in the Context of Library Practice of the 20s - early 30s of the XX century]. Visnyk Knyzhkovoi palaty. No 7, s. 1-6. (in Ukrainian)

Tymoshenko, I. (1999). Diialnist Kabinetu po vyvchenniu knyhy i chytacha v UNIK (1926-1931). [Activities of Book and Reader Study Cabinet of UNIC (1926-1931)]. Bibliotechnyi visnyk. No 2, s. 17-20. (in Ukrainian)

Ivanushkyn, V. (1926). Problema chytachivstva ta yii vyvchennia (Formy orhanizatsii ta metody roboty Kabinetu vyvchennia knyzhky ta chytacha pry U.N.-D.I.K.). [The Issue of Readership and its Study (Forms of Organization and Methods of Work of Book and Reader Study Cabinet of UN-DIC)]. Kyiv : UNIK, 1926. 32 s. (in Ukrainian)

Demchuk, N. (2008). Synkretychna pryroda teorii bibliopedahohiky ta bibliopsykholohii (komparatyvistychna studiia knyhoznavchykh paradyhm D. Balyky ta M. Rubakina). [Syncretic Nature of the Theory of Bibliopedagogy and Bibliopsychology (Comparativistic Studio of bibliological paradigms of D. Balyka and M. Rubakin)]. Visnyk Lvivskoho universytetu. Seriia knyhoznavstvo, bibliotekoznavstvo ta informatsiini tekhnolohii. Lviv, Vyp. 3. S. 174. (in Ukrainian)

Biblioteka i chytach na Ukraini: Pratsi Kabinetu vyvchannia knyhy y chytacha: zb. pershyi [Library and Reader in Ukraine: Proceedings of the Cabinet for Research of Books and Readers] / za red. D. Balyky; Trudy UNIK. T. 2. Kharkiv; Kyiv : DVU, 1930. 240 s. (in Ukrainian) 
Інноватика у вихованні. Випуск 11. Том 1. 2020.

Postanova Rady narodnykh komisariv UkSSR. Pro reorhanizatsiiu naukovodoslidchoho instytutu knyhoznavstva (1936). [Resolution of the Council of People's Commissars of the UkSSR "On the Reorganization of the Research Institute of Bibliology”. Biblioteka u sotsialistychnomu budivnytstvi. No 9. S. 51. (in Ukrainian)

\title{
SPECIFICITY OF THE ACTIVITY OF BOOK AND READER STUDY CABINET AT THE UKRAINIAN SCIENTIFIC INSTITUTE OF BOOK STUDIES (1926-1936)
}

\author{
Liudmyla Balika \\ Candidate of Pedagogical Sciences, Associate Professor, \\ Associate Professor at the Department of Theory and Methods of Education, \\ Rivne State University for the Humanities, \\ Rivne, Ukraine \\ ORCID: 0000-0003-0042-7744 \\ e-mail: luidmyla.balika@rshu.edu.ua
}

\begin{abstract}
It is established in the paper that in Ukraine there is a significant decrease of reading interest. The current crisis of reading is recognized as a state problem. The state has adopted a number of normative documents, the overarching goal of which is to revive the social significance of books and reading as a process of cultural, spiritual, professional and intellectual enrichment. The analysis of the activities of Book and Reader Study Cabinet of the Ukrainian Scientific Institute of Book Studies (1926-1936) was carried out. Emphasis is placed on the fact that the Cabinet was the center of scientific research of reading and readers, which was facilitated by highly qualified specialists who developed the theoretical and methodological foundations of the research. It is noted that in different times the Cabinet was headed by V. M. Ivanushkin (1926-1927), D. A. Balyka (1927-1930), and N. M. Birkina (1931-1936). The main theoretical problems that the Cabinet planned to work on were highlighted: psychology of book influence in general; the content of the book in terms of bibliopsychology; reading as a problem of literary criticism; psychology of perception of a literary work; the place of the reader's history in the history of literature; the history of reader in Ukraine; principles of writing a popular book; modern Ukrainian popular book, etc. It was focused on the fact that the Cabinet as a research institution was developed in three stages: the first development of tasks and installations, organization of research groups; the second collection, processing and systematization of material for research; the third - publication of research results in periodicals and a collection of "Proceedings of the Cabinet of Readers". One of the main tasks was a comprehensive study of the complex "book reader". It was turned out that the activity of the Cabinet was aimed at organizing and conducting an All - Ukrainian study of the state of libraries and their work with readers, study of readership in libraries, research of reading fiction by working youth.
\end{abstract}

Keywords: Book and Reader Study Cabinet, Ukrainian Scientific Institute of Bibliology, book - reader complex, V. M. Ivanushkin, D. A. Balika, N. M. Birkina, Ukrainian educational and cultural institutions of 1920-1930.

Стаття надійшла до редакиії 04. 05. 2020 р. 